\title{
THEORETICAL PRELIMINARY RESEARCH OF AVIATION FUEL QUALITY CONTROL AS A TOOL FOR ENSURING THE SAFETY OF CIVIL AVIATION AIRCRAFT
}

\author{
Anatoly BRAILKO, Boris ELISEEV, \\ Moscow State Technical University of Civil Aviation, Kronshtadtskiy Bul'var, 20, Moscow, Russia \\ Victoria ZHARKOVA*, Vladimír NĚMEC \\ University of Pardubice, Faculty of Transport Engineering, Department of Transport Management, \\ Marketing and Logistics, Studentská 95, Pardubice 2, 532 10, Czech Republic \\ *Corresponding author. E-mail: viktoria.zharkova1@gmail.com
}

\begin{abstract}
The article discusses the elements of creating and implementing innovative technological equipment for the refueling complex laboratory «TZK» - a single integrated quality management system for aviation fuel supply for civil aviation aircraft, by increasing the system's capabilities by adding new components. The introduction of digital technology, tools, industry 4.0 and trends of automation, digitalization, digitalization of modern aviation fuel aircraft HA become a basic tool of refueling complexes HECTARES in the security of aircraft, civil aviation, which is especially important in high intensity operations. The article presents a theoretical preliminary research of the issue before the following research from the theoretical level to the practical level of problem solving.
\end{abstract}

Keywords: fuel supply system; JFTOT (Jet Fuel Thermal Oxidation Tester); thermal stability in dynamic conditions; safety.

\section{INTRODUCTION}

In recent decades, there has been a sharp increase in the volume of traffic in civil aviation in Russia, and for this reason, there is an increase in the number of refueling operations performed when preparing aircraft for departure, which in turn leads to a significant load on the personnel and equipment of refueling complexes (hereinafter referred to as refueling complexes) airports.

At the same time, the main task of the refueling complex is the organization of production processes and quality control of aviation fuel in conditions of strict adherence to technological schedules (slots) of aircraft refueling in preparation for departure. [4]

One of the main tasks of organizing the production of the airport's refueling complex is the tasks of planning and managing resources with continuous quality control of aviation fuel in conditions of continuous provision of implementation of the flight plan.

\section{AVIATION FUEL QUALITY CONTROL IS A TOOL FOR ENSURING THE SAFETY OF CIVIL AVIATION AIRCRAFT}

Assurance of flight operations safety. remains one of the most important problems at present. During the entire time that aviation has existed, there have been many incidents, accidents, disasters, crashes, the reasons leading to these events were: crew errors, equipment malfunction, errors in aircraft maintenance by technical personnel, poor weather conditions, refueling with substandard fuel and many other factors.

In solving the problem of flight safety, special attention should be focused on the quality of the fuel refueled in the aircraft, since one of the components of flight safety is the trouble-free operation of the fuel system. The presence of water, mechanical contamination, resins, microorganisms and bacteria in 
the fuel does not have a beneficial effect on the operation of the aircraft fuel system, and hence on the safety of flights in general $[1,3,5]$.

In order to assess the impact of the quality of jet fuel purification on flight safety, the authors of the work analyzed statistical data on incidents, accidents and disasters with the aircraft of commercial civil aviation of the Russian Federation in the period from 1990 to 2016, recorded in the database of the Automated Flight Safety Assurance System according to code "028 fuel system" (GOST 18675 [16]). Total 213 events were analyzed. Statistical data are ranked by groups $[5,6,12,15]$. Systematized information on the causes of accidents is presented in Table 1.1.

Analysis of statistical data $[5,6,12,15]$. shows that six groups of events related to the operability of the fuel system are registered: substandard aviation fuel (first place in the number of events - 55.40\%), aircraft failures (second place $-34.74 \%$ ), human factor (third place $-7.98 \%$ ), poor-quality repair of the fuel system (fourth place - 0.94\%), deficiencies in the technology of maintenance of the fuel system and the impact of weather conditions (fifth and sixth places $-0.47 \%$ each). That is, the number of events with aircraft due to poor quality of aviation fuel is 1.24 times higher than the number of events caused by all other reasons.

Table 1 Causes of incidents and accidents classified according to code 028 fuel system

\begin{tabular}{|c|c|c|}
\hline The cause of the accidents & $\begin{array}{l}\text { Number of accidents due } \\
\text { to the analyzed cause / } \\
\text { (number) of them due to } \\
\text { filling of substandard } \\
\text { fuel }\end{array}$ & $\begin{array}{l}\text { Percentage of } \\
\text { accidents for the } \\
\text { analyzed reason in } \\
\text { the total number of } \\
\text { events, } \%\end{array}$ \\
\hline $\begin{array}{l}\text { Substandard aviation fuel (without specifying the } \\
\text { reason for substandardness) / (including aviation } \\
\text { fuel refueled before the flight) }\end{array}$ & $34 / 32$ & 15,96 \\
\hline $\begin{array}{l}\text { Substandard aviation fuel (water in fuel) / } \\
\text { (including aviation fuel refueled before the flight) }\end{array}$ & $29 / 25$ & 13,62 \\
\hline $\begin{array}{l}\text { Substandard aviation fuel (mechanical } \\
\text { contamination in the fuel) / (including aviation } \\
\text { fuel refueled before the flight) }\end{array}$ & $17 / 11$ & 7,99 \\
\hline $\begin{array}{l}\text { Substandard aviation fuel (mechanical } \\
\text { contamination in combination with water and } \\
\text { other contaminants in the fuel) / (including } \\
\text { aviation fuel refueled before the flight) }\end{array}$ & $9 / 8$ & 4,22 \\
\hline $\begin{array}{l}\text { Substandard aviation fuel (destruction products of } \\
\text { the fuel tanker truck structure) / (including } \\
\text { aviation fuel refueled before the flight) }\end{array}$ & $2 / 2$ & 0,94 \\
\hline $\begin{array}{l}\text { Substandard aviation fuel (absence, insufficient or } \\
\text { excessive concentration of anti-water } \\
\text { crystallization liquid in the fuel) / (including } \\
\text { aviation fuel refueled before the flight) }\end{array}$ & $14 / 10$ & 6,57 \\
\hline $\begin{array}{l}\text { Substandard aviation fuel (chemical pollution) / } \\
\text { (including aviation fuel refueled before the flight) }\end{array}$ & $9 / 4$ & 4,22 \\
\hline $\begin{array}{l}\text { Substandard aviation fuel (fuel discrepancy with } \\
\text { Specifications) / (including aviation fuel refueled } \\
\text { before the flight) }\end{array}$ & $3 / 2$ & 1,41 \\
\hline $\begin{array}{l}\text { Substandard aviation fuel (uncertified aviation } \\
\text { fuel) / (including aviation fuel refueled before the } \\
\text { flight) }\end{array}$ & $1 / 1$ & 0,47 \\
\hline $\begin{array}{l}\text { Substandard aviation fuel (total) / (including } \\
\text { aviation fuel refueled before the flight) }\end{array}$ & $118 / 95$ & 55,40 \\
\hline Failures in the operation of units, assemblies of & $74(34 / 18)$ & 34,74 \\
\hline
\end{tabular}




\begin{tabular}{|l|c|c|}
\hline $\begin{array}{l}\text { parts of the aircraft fuel systems (total) (of which } \\
\text { aircraft of } 1 \text { - 3 classes of Russian and foreign } \\
\text { production }\end{array}$ & & \\
\hline Human factor (not closing the fuel filler neck) & 2 & 4,22 \\
\hline $\begin{array}{l}\text { Human factor (poor quality maintenance of the } \\
\text { fuel system) }\end{array}$ & 1 & 0,94 \\
\hline $\begin{array}{l}\text { Human factor (insufficient control by the crew } \\
\text { over the sequence of the exhaustion of aviation } \\
\text { fuel in flight) }\end{array}$ & 1 & 0,47 \\
\hline $\begin{array}{l}\text { Human factor (landing with fuel capacity under } \\
\text { the minimum threshold) }\end{array}$ & 1 & 0,47 \\
\hline $\begin{array}{l}\text { Human factor (intentional refueling of } \\
\text { substandard aviation fuel by the crew into the } \\
\text { aircraft fuel tanks) }\end{array}$ & 1 & 0,47 \\
\hline $\begin{array}{l}\text { Human factor (intentional refueling by the crew } \\
\text { into the aircraft fuel tanks of aviation fuel, the } \\
\text { grade of which is not approved for use on this } \\
\text { type of aircraft) }\end{array}$ & 1 & 0,47 \\
\hline Human factor (violation of refueling technology) & 1 & 0,47 \\
\hline $\begin{array}{l}\text { Human factor (deliberate modification of the fuel } \\
\text { system design, leading to fuel leakage in flight) }\end{array}$ & 1 & 0,47 \\
\hline Human factor (total) & 1 & 7,98 \\
\hline Poor quality fuel system repair (total) & 1 & 0,94 \\
\hline $\begin{array}{l}\text { Deficiencies Inadequacy of maintenance } \\
\text { technology (total) }\end{array}$ & 1 & 0,47 \\
\hline Impact of weather conditions & 1 & 0,47 \\
\hline Total & 100,00 \\
\hline
\end{tabular}

Thus, the most important factor affecting the reliability of the aircraft fuel system is the conditionality of aviation fuel.

Aviation fuel supply organizations have specialized laboratories for the implementation of multistage quality control of aviation fuels and lubricants and special fluids. These laboratories, in the process of control, form a quality certificate for aviation fuels and lubricants and special liquids, which determines the suitability of the product issuance for refueling aircraft. One of the largest laboratories in Russia for quality control of aviation fuels and lubricants and special fluids operates at Vnukovo airport. Its activities are aimed at ensuring the safety and regularity of flights of a modern domestic and imported aircraft fleet. The fuel and lubricants laboratory of closed joint-stock company "TZS" of Vnukovo airport is certified in the civil aviation system. The scope of the laboratory includes the study of 32 different types of aviation fuels and lubricants and special fluids based on 31 quality indicators. $[9,10]$. The laboratory staff is certified, has special education and high qualifications.

Currently, along with the construction of a centralized aircraft refueling system at Vnukovo airport, reconstruction of existing facilities, the company's management pays special attention to equipping the laboratory with fuels and lubricants.

Over the past two years, significant amount of action steps was taken to develop the laboratory base "Fuel and filling service":

- a step-by-step replacement of outdated equipment with high-tech and modern devices and analyzers from leading world manufacturers was carried out;

It should be noted that against the background of an increase in the volume of fuel consumed and, as a consequence, an increase in the number of analyzes, the laboratory ensures continuous operation. There are automatic devices for determining the main, most informative physical and chemical parameters in duplicate. Manual control methods are available for conducting arbitration analysis. 
- acquired reference samples to achieve the uniformity of measuring instruments, taking into account international requirements;

- updated bank of chemical reagents, solvents, consumables;

- to enhance quality control of aviation fuel, in April 2013, was purchased an automatic analyzer of thermal oxidative stability of aviation fuels JFTOT III including a tester for oxidation of aviation fuels at high temperatures (Jet Fuel Thermal Oxidation Tester - JFTOT) according to the ASTM D 3241 and GOST R 52954 method.

The purchase of the device was prompted by repeated recommendations from the International Air Transport Association (IATA) inspections. This recommendation has been implemented to date.

The JFTOT analyzer allows you to evaluate the thermal-oxidative stability of aviation fuel in conditions close to operating conditions. Similar kind of analyzer was purchased for the first time for the laboratory of the organization of aviation fuel supply for civil aviation. Vnukovo Airport is the first airport in Russia that has the ability to test jet fuel just before refueling aircraft. Fuel could be tested for its oxidation stability at high temperatures and to determine the tendency to form decomposition products during flight.

The purpose of the JFTOT III System is to detect the formation of depositions from aviation fuel when it is heated in the presence of dissolved oxygen and a metal surface. To determine the degree of fuel degradation due to oxidation, the level of depositions is measured and compared with a standard.

As a result of exploitation, laboratory personnel have once again confirmed that JFTOT provides highly accurate data collection and requires minimal test time. JFTOTIII continuously monitors all setup and test steps. The device provides an automatic check of the settings, blowing the sample with air.

Built-in safety system automatically stops testing in case of leakage of the test sample. The device is equipped with a computer with the latest software for control, data collection and processing, diagnostics of all systems, touch color monitor. It should be noted that a simplified thermocouple alignment unit inside the tube is provided for calibration. There is also a lightweight sample loading and unloading system. Automatic deposit assessment apparatus with built-in video camera and LCD screen tests the surface of the test tube and gives the result, also allows you to project the surface of the test tube onto the device screen, where you can visually observe the presence or absence of uncharacteristic deposits.

Since the beginning of the use of the analyzer at the fuel and lubricants laboratory, there were carried out comparative tests of fuel of the TS- 1 and RT brands of various manufacturers. $[9,10]$. A program is currently being developed to test aviation fuel at the Jeftot facility for optimal control to ensure the safety and regularity of aircraft operations. Strengthening the quality control of aviation fuel is associated with an increase in the dynamics of fuel movement through the fuel-filling company, expansion, comprehensive modernization of existing production facilities, and the commissioning of the facilities under construction of the centralized fueling system of Vnukovo airport. To date, work is underway to put into operation the first stage of tanks - these are two RVS-5000 tanks of the tank farm of the central gas station system. Aviation fuel quality control using the Jeftot analyzer allows testing fuel from new tanks with an internal anti-corrosion coating, a new pipeline system, and new equipment used in the technological system of aviation fuel supply. A comprehensive approach to the quality of aviation fuel makes it possible to make an important contribution to the fulfillment of the company's main task - continuous aviation fuel supply to Vnukovo airport, taking into account the high level of reliability of aviation equipment. Fuel quality is one of the main factors affecting assurance the required safety of aircraft flights. The laboratory carries out strict quality control at all stages of the technological process in order to issuance conditioned aviation fuel for refueling of aircraft.

Thanks to the purchase of unique automatic analyzers, the laboratory staff is acquiring new topical quality control methods that make it possible to most fully identify aviation fuel taking into account international requirements.

In June 2013, in the process of planned international inspection by IATA, inspection control for certification [7,9]. The Federal Air Transport Agency (Rosaviatsiya) with the involvement of specialists from the Federal State Unitary Enterprise State Research Institute of Civil Aviation (FGUP 
GosNII GA) noted significant progress in the development of the laboratory facilities and the activities of the laboratory of fuels and lubricants in general.

The laboratory of fuels and lubricants took part at the invitation of the Research and Production Association "INTEGRSO" in the interlaboratory tests of the certified reference materials, in Russia known as GSO 9382-2009. At present, a decision has been made to conduct interlaboratory tests of a control sample of aviation fuel between the laboratories of the airports Vnukovo, Domodedovo, Sheremetyevo and FGUP GosNII GA in the 3rd quarter. [7]. On the basis of the laboratory is organized practice of students - graduates of the Egorievsk Aviation Technical College named after V.P. Chkalov. The fuel and lubricants laboratory of closed joint-stock company "TZS" looks confidently into the future and is ready to perform the assigned tasks with high results.

\section{CONCLUSIONS}

Modernization and automation of quality control of aviation fuel supply is particularly relevant due to the high cost of the business, and what is especially important is the high responsibility for flight safety.

The refueling digital laboratory is a convergence where the capabilities of many constituent components converge. The use of modern microprocessor hardware and software ensures the development of a digital refueling complex and its integration into the production information network of the airport.

A modern refueling complex is already unthinkable without the transformation of systems, without the transformation of existing, rapidly aging technologies. Rapid development and progress, in the era of the 4th industrial revolution, changes our understanding of approaches to the introduction of automation, improving the quality of aviation fuel supply and refueling aircraft at civil aviation airports.

\section{References}

[1] Aviation accidents, incidents and air crashes in the USSR and Russia. Airdisaster.ru, 20062012. Available at: http://www. airdisaster.ru/

[2] Aviation Safety Network [Electronic resource] / Flight Safety Foundation: aviation-safety.net, 1996-2012. Available at: http://aviation-safety.net/statistics/.

[3] Boychenko, S. V. \& et al.: Motor Fuels and oils for modern technology. NAU, 2005. 216 p.

[4] Brailko A. A., Gromov O. V., Druzhinin L. A. Digital technologies - base of digital economy of fuel filling complexes of civil aviation airports. Scientific Bulletin of MSTU GA. 2020;23(4):20-32. DOI: https://doi.org/10.26467/2079-0619-2020-23-4-20-32

[5] Gishvarov, A. S. \& et al.: Operational reliability of aircraft fuel systems. Textbook. Manual. Ufa: UGATU, 2008. 298 p.

[6] Konyaev, E. A. \& et al.: Problems of accuracy of a fixed standard for the duration of defending aviation fuel. Scientific Bulletin of MSTU GA, 2014. № 206 (08). Pp. 131-136.

[7] Proceedings of the international scientific and technical conference, FAU 25 GosNII. Improvement of the aviation fuel control system in the airport's aviation fuel supply equipment. 2014.

[8] Reznikov, M. E. \& et al.: Chemistry and aviation fuels and lubricants. Kharkiv: vvia edition named after prof. N.E. Zhukovsky, 1977. 300 p.

[9] Guidelines for receiving, storing, preparing, issuing for refueling and quality control of aviation fuels and lubricants and special liquids in the enterprises of the GA of the Russian Federation: order of the air transport Department of the Ministry of transport of the Russian Federation, 1992. 114 p.

[10] Guidelines for the supply of jet fuels in civil aviation. ICAO, DOC9977 AN/489, 2012, 40 p.

[11] Tikhonov, N. I. \& et al.: Ensuring the purity of fuels in the conditions of airfield operation Operational properties of aviation fuels: Tr. conferences. Kiiga. Kiev, 1972. Pp. 85-89. 
[12] Timoshenko, A. N. \& et al.: Problems of using a fixed standard for the duration of defending aviation fuel in the fuel and lubricants services of airports. Scientific Bulletin of GosNII GA, No. 4, 2014. Pp. 80-85.

[13] Uryavin, S. P. \& et al.: Some modern problems that threaten the safety of aircraft flights. Information Collection of the Association of organizations of aviation fuel supply for civil aviation air suteords, No. 7, 2012. Pp. 62-63.

[14] Yakovleva, A.V. \& et al: Influence of aviation fuel quality on flight safety and the environment. Institute of environmental safety of the National Aviation University. Kiev: The Science that novac, Vol. 9, No. 4, 2013. Pp. 25-30.

[15] Yanovsky, L. S. \& et al: Engineering foundations of aviation chemmotology. Kazan: publishing house of Kazan. UN-TA, 2005. 714 p.

[16] GOST 18675-2012. Operational and repair documentation for aviation equipment and purchased products for it. Moscow: STANDARTINFORM, 2009. $92 \mathrm{p}$.

Received 12, 2020, accepted 12, 2020

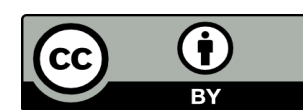

Article is licensed under a Creative Commons Attribution 4.0 International License 